\title{
P19 - Assessment of quality of life in Uruguayan children with atopic eczema and their families
}

\author{
Iris S Ale*, Ingrid Rivas, Mariela Alvarez \\ From 3rd Pediatric Allergy and Asthma Meeting (PAAM) \\ Athens, Greece. 17-19 October 2013
}

\section{Background}

Skin diseases produce a negative impact on the psychoemotional state, social relationships and daily activities. This effect should be particularly important during childhood, a critical period for physical and psychosocial development. However, there is a scarcity of publications on the impact of dermatological diseases in the pediatric population.

Atopic eczema (AE) is a chronic eczematous and pruritic skin disease that may affect the physical, social, and emotional functioning of the affected children as well as their families.

\section{Methods}

One hundred and twenty children (69 females and 51 males) from 6 months to 14 years old, attending the Department of Dermatology at the Pediatric University Hospital in Montevideo, Uruguay, with a confirmed diagnosis of $\mathrm{AE}$-according to the criteria of Hanifin and Rajka- and their parents, entered the study. As a control group we included 100 healthy children of comparable age, gender and socioeconomic background, as well as their parents. The data collection instruments were the Children's Dermatology Life Quality Index (CDLQI), the Infant's Dermatitis Quality of Life Index (IDQOL) and the Dermatitis Family Impact Questionnaire (DFI). Severity of $\mathrm{AE}$ was assessed with the SCORAD.

\section{Results}

The median score for the IDQOL was 8.92 (range 2-23, $\mathrm{n}=66)$, for the CDLQI, $10.84(0-26, \mathrm{n}=54)$, and for the DFI, $8.17(4-25 . \mathrm{n}=120)$. All these values were significantly different from the control subjects. There was no significant gender difference.

\footnotetext{
Department of Dermatology and Department of Allergology, Republic
} University of Uruguay, Montevideo, Uruguay

\section{Conclusion}

The results show that AE significantly impairs the children's quality of life in all age groups and also the quality of life of their families. We suggest the regular evaluation of the quality of life in the clinical management of children with AE.

Published: 28 February 2014

doi:10.1186/2045-7022-4-S1-P74

Cite this article as: Ale et al:: P19 - Assessment of quality of life in

Uruguayan children with atopic eczema and their families. Clinical and Translational Allergy 2014 4(Suppl 1):P74.

Submit your next manuscript to BioMed Central and take full advantage of:

- Convenient online submission

- Thorough peer review

- No space constraints or color figure charges

- Immediate publication on acceptance

- Inclusion in PubMed, CAS, Scopus and Google Scholar

- Research which is freely available for redistribution 